\title{
Narrative Features in The Lady in the Van
}

\author{
Xiaojuan Liu \\ School of Foreign Languages, Capital Normal University, Beijing City, China; \\ School of Humanities, Tiangong University, Tianjin City, China
}

\begin{abstract}
The Lady in the Van is about the odd friendship between Bennett, a writer, and Miss Shepherd, an eccentric homeless woman. This paper intends to discuss the narrative features of the film version from David Bordwell's three dimensions (narration, plot structure and story world) of film narrative. The film presents us with a unique point of view, a seemingly disjointed but implicitly connected plot structure, and a story world in which the characters have their own goals to achieve. Bennett and Miss Shepherd have got to know each other better in fifteen years. Miss Shepherd is Bennett's guide in life, teaching him how to write and how to get along with his mother.
\end{abstract}

Index Terms - narration, plot structure, story world

\section{INTRODUCTION}

Alan Bennett's The Lady in the Van was originally a short autobiographical memoir published in the London Review of Books in 1989. In 1999, Bennett adapted the story into a two-act play. Dan McIntyre, a British cognitive stylist, based on Fowler's (1977) work on mind style, argues that Miss Shepherd's flawed inductive in the play shows a deviant mind style and also uses Harris' (1984) sociological notion of paradigms of reality to analyze the mind style (Dan McIntyre, 2005, p. 21). McIntyre, based on the study of Emmott's (1997) contextual frame theory and Ryan's (1991) approach to possible worlds, develops his modified version of deictic shift theory (DST). He thinks that the impossible occurrences in the play can be explained, which can reveal how the playwright Bennett in the play is able to create innovative and interpretatively meaningful viewpoint effects throughout the play. (Dan McIntyre, 2006, p. 185)

On the basis of McIntyre's study of the point of view in the play, this paper intends to explore the narrative features of the film version of The Lady in the Van from David Bordwell's three dimensions (narration, plot structure and story world) of film narrative. The film version was produced by BBC Films in November 2015, directed by Nicholas Hytner and starring Maggie Smith and Alex Jennings. The film tells the story of a cranky, homeless woman Miss Shepherd who spends 15 years on the driveway of Bennett's house in Camden, London, England, in the 1970s. Bennett provides her with a temporary shelter, and the town neighbors offer their help in the guise of kindness. Social workers offer their sympathy and care. However, Miss Shepherd is still ungrateful for what they have done for her. With a unique point of view, complex plot structure and several embedded story worlds, the film gradually reveals the past of a gifted lady. Lurking beneath the surface of her madness we find her reason, her obsession with music, her devotion to God, her profound knowledge of family relationships. Looking back on her lonely and miserable life, Bennett touches on the repressed humanity.

\section{NARRATIVE FEATURES}

\section{A. Narration}

Narration is the moment-by-moment flow of information about the story world. (David Bordwell, 2008, p. 90) The study of narrative films treats film holistically. (David Bordwell, 2008, p. 94) The symmetries between openings and closings suggest that narration is a system that's put into motion across the whole film. All the factors we normally associate with narration - play with the order of events, shifts in point of view, and voice-over commentary - shape our overall experience. (David Bordwell, 2008, p. 95)

At the beginning the film, a van is driving down the road and there is a loud crash. The driver does not stop. When the van turns to a fork in the road, there is a patch of blood on the front window. The frightened driver pulls away again and a policeman watches the van leave. At the end of the film, Miss Shepherd appears before Bennett, along with the young lad who was killed in the opening scene. Throughout the film, she always thinks that she is to blame for the accident, and thereafter lives in fear of arrest. It turns out that the young lad on a motorbike comes around a corner too fast and smashes into her vehicle. It is not her fault. The opening and the closing form a complete narration.

The events in the film are trivial but closely related, reflecting the British society and people's spiritual world at that time. The film revolves around Miss Shepherd, Bennett and their neighbors. The neighbors don't want her to live near their house. Miss Shepherd always moves her van and becomes the discordant voice of the street. A beat-up van seems to be a real eyesore. She often goes out in her car and seems to know some places in London. She often goes to church to confess. Miss Shepherd is a regular shopper who lives a very full life. But it's weird. She can even speak French fluently. Social workers pay a regular visit to her and bring her some clothes. But She is very choosy about the clothes 
they send and thinks that green is not her colour and dumps the green coat. The events described in the film are thus revealed to the audience bit by bit. Her weird reactions are all about her past. The audience begin to know the story of her youth in the 1970s: she was the virtuoso pianist Alfred Cortot's pupil and has to go over to Paris for lessons. She used to practise all day long. The nuns put a stop to that. The mistress of the novices told her that she could not play the piano, it's God's will. She should not argue, she'd never make a nun if she argues. Her practising had become praying.

Li Xianjie (1999) points out that the narration of "I" in films can be divided into "outside" and "inside". The inside "I", as both a narrator and a character (the protagonist), is presented in the film and participates in the narration of the events (p. 279). The focus of the narration of inside "I" is mainly the character's reaction to the event, feelings and how to deal with the state of mind and behavior, and the emphasis is on pouring out the "inner voice" (p. 280). Bennett in the film belongs to the inside "I" and often uses voice-over (narration or internal dialogue) to develop the film.

As for the shifts in point of view in the play version, McIntyre uses AB1 and AB2 in the play to refer to two different Bennetts, namely the character and the narrator. When readers read the play, they may find it hard to determine which Bennett is speaking. McIntyre uses the revised version of DST theory to explain the complexity of point of view when analyzing the play. Deixis refers to pointing or situating. Nina Nørgaard, Rocío Montoro and Beatrix Buss (2017) think that the notion of deixis can be understood both in a literal sense ('pointing in space', 'pointing in time', 'pointing in discourse') and in a metaphorical sense ('placing in the social scale' or 'situating yourself psychologicallly and emotionally'). (p. 97) DST is less concerned with establishing the ways in which spatio-temporal parameters (among others) are marked in language but more with the cognitive repositioning into the story world of fiction that readers are able to experience (p. 92). The core concept of DST is the deictic center and refers not just to a speaker or hearer's location in space and time, but also to their position in a social hierarchy. (Dan McIntyre, 2006, p. 92) As for how to distinguish AB1 from AB2, McIntyre gives a detailed analysis of some scenes according to AB1 and AB2's personalities. We may refer to the linguistic cues provided by AB2 and know that AB2 starts a new deictic field for $\mathrm{AB} 1$ but still stays there with $\mathrm{AB} 1$ since $\mathrm{AB} 2$ has defined the parameters of his deictic field by giving us the temporal and spatial co-ordinates of his deictic center. Readers' default deictic field in the Actual World will have decayed significantly and they will focus on AB1's deictic field, making it primed as well as bound. (p. 165)

In the film version, it is not so difficult to determine the shifts in point of view. It is rather interesting when we see $\mathrm{AB} 1$ and $\mathrm{AB} 2$ are conversing with each other. Maybe we can say it is rather ironic if we know the loneliness of Bennett and his relationship with his mother "Mam" whose affection almost smothers him. However, he can get along with Miss Shepherd and tolerate her. How to distinguish these two Bennetts? We may judge by how they dress. At the beginning of the film, Bennett who wears a shirt, as a writer, sits at a typewriter and types what he thinks about Miss Shepherd's various odours. The narrator's voice-over continues as Bennett looks up and sees Miss Shepherd coming down the stairs after using the lavatory. Bennett stands up and says, "Tell her." Then the scene changes to the outside, and Bennett who wears a sweater tries to negotiate with Miss Shepherd about her habit of using the lavatory, but in vain. Miss Shepherd thinks that the lavatories on the bottom of the High Street smell and she is by nature a very clean person. Later he comes back and looks rather helplessly at the other Bennett who wears a shirt. The voice-over continues: the writer is double. There is the self who does the writing, and there is the self who does the living. And they talk. They argue. Writing is talking to oneself. And I've been doing it all my life. A writing self and a living self can also be viewed as the writer-who-writes and the writer-who-lives. They live in the same house and accompany each other, the writer-who-lives often converses with Miss Shepherd and provides material for the writer-who-writes. In the real life of the film, AB1 or the writer-who-lives is always there and communicates with Miss Shepherd. AB2 or the writer-whowrites is a narrator who is always an onlooker and never appears in front of Miss Shepherd except for the last scene. Later we will discuss this point in the part of story world.

\section{B. Plot Structure}

Bordwell (2008) argues that the term plot structure can mean many things and it can refer to the way in which the syuzhet is patterned in itself, without regard to the strategies by which the narration presents the fabula information. (p. 102) He mentions Kristin Thompson's revision of film structure in his book: Setup section, Complicating action, Development, Climax and Epilogue. The Setup section endows the protagonist with a set of goals; the Complicating Action recasts or even cancels the initial goals and ends with a new set of circumstances governing the action; the Development ends with a piece of action that puts the achievement of goals into a crisis; the Climax is the final section in which the protagonist definitely achieves or doesn't achieve the goals and often followed by an Epilogue, which asserts that a stable situation has been achieved. (p. 105)

The Setup section of the film tells the story of the audience in the 1970 s enjoying the elegant music played by the orchestra in London's Gloucester Crescent. Bennett, as a writer, is writing his play on a typewriter about Miss Shepherd's various odours, a mixture of elegance and poverty. The scene cuts to five years ago when the agent took him to see a house for sale and he first saw this house.

Then we have the Complicating section. The film is about Bennett's relationship with Miss Shepherd. Neighbors often resentfully loot at Miss Shepherd when she takes turns camping out at their respective doorways. Some people send pears from their garden in Suffolk and snacks to her, but she does not appreciate it. Mrs. Vaughan Williams gets some information about Miss Shepherd and suggests that Bennett put Miss Shepherd into his play, but Bennett disagrees. Miss Shepherd's conversation with Bennett often violates some basic conversational rules. Miss Shepherd 
has her own channel of communication, that is the Virgin Mary. Everything is in the name of God: as for parking the van, she has guidance from the Virgin Mary, she also follows the tips on Christian Parking. Bennett can't communicate with her and sometimes he teases her about her god's ability to solve practical problems for her. Bennett thinks that she is talking gibberish when she mentions that there may be a gray snake which is keeping close to the wall and is headed for her van. But to his surprise, the snake appears in her neighbour's house the next day. Bennett's mother talks about the massive birds on the wall and he thinks that she is imagining things but later sees four peacocks from the hall lined up on the garden wall. He makes a connection between his mother and Miss Shepherd and cannot understand them. They are just like a deluded woman standing at the northern and southern gates of his life. When Miss Shepherd hears the music played by children in her neighbourhood, she thinks that they are making too much noise. She wants to change cars, painted yellow and covered with the union flag with the Queen's portrait. And she is constantly harassed by a man who calls her Margaret. Is she Mary or Margaret? Bennett plays the music deliberately, but it offends Miss Shepherd.

It's about 50 minutes when the Development section starts. The mystery will gradually unravel. Miss Shepherd has introduced herself to a social worker as Mary, but Bennett doesn't know Miss Shepherd's name. The social worker thinks that they lack communication and suggests that he call her by her name and talk things through. Bennett refutes the social worker's suggestion and thinks there is no through, it is impossible to talk things through with someone who has conversations with the Virgin Mary. Miss Shepherd drives freely, walks along the beach, eats free cookies at the senior citizens' club and enjoys her favorite melodies. The scene cuts to an intersection where Miss Shepherd is on her knees confessing. Bennett is very worried about the long absence of the elusive Miss Shepherd, fearing that it would be the end of the story. Miss Shepherd suddenly appears from behind him and startles him. She is angry with him for having opened her van door without permission. To her, it is her private place, the untouchable place. Miss Shepherd spends her days shopping in a wheelchair. She even offers some insightful observations and thinks that he is using her mother and should be ashamed of himself. Later she says she has to go to mass and it is an anniversary and a day of obligation. Someone who died is purgatory and needs her prayers. Bennett becomes truly involved in Miss Shepherd's life and turns to nuns in a convent for help. He thinks that they could help the ailing Miss Shepherd, but the nun refuses to help a difficult woman. However, Miss Shepherd is unkind to Bennett who has helped her a lot. When the social worker views him as a carer for Miss Shepherd, he reacts angrily to that reference. He thinks that it is ungrateful of Miss Shepherd. He says that he isn't a carer and he is here, she is there. There is no caring. Bennett also says he has coped with this woman on a daily basis for the past 15 years, she is a bigoted, blinkered, cantankerous, devious, unforgiving, self-serving, rank, rude, car-mad cow.

When Miss Shepherd is about to die, the staff member at the day center, not sick of her soul smell, carries her to the car. Bennett thinks that there is a vagabond nobility about her when she slowly rises above the level of the garden wall. She looks like a derelict Nobel Prize winner. Her grimy face is set in a kind of resigned satisfaction. She is given a good bath and also plays her favorite tunes. However, the scene of playing the piano suddenly cuts to her lying in the van. Miss Shepherd tells Bennett something from the bottom of her heart that may be the Climax in the film. She recalls her past and thinks playing comes easier than praying. She can play in the dark, C major, D minor. The keys are like rooms: dark rooms and light rooms. Music is like a mansion. She doesn't understand why people are supposed to avoid it. The confessor tells her that is another vent devil could creep through. So he outlaws the piano and puts paid to music generally. He says dividends would accrue in terms of growth of the spirit. They shake hands and say their farewells. And then the Epilogue. The dead Miss Shepherd shows up at the cemetery and makes a new friend, the young man she didn't run over. The film ends with her ascension.

\section{Story World}

Bodwell (2008) thinks that the story world of includes its agents, circumstances, and surroundings (p.90). Based on Ferdinand Brunetiere's saying, a novel might center on characters who merely respond to external circumstances, stage plays demand a character who vigorously pursues his or her desire. Hollywood and other film industries also have this model and human beings tend to seek the intentions behind every action and to recognize that society is riddled with clashes between individuals, all eager to fulfill their own needs. (p. 117)

McIntyre (2006) uses the term "frame" narration proposed by Richardson (1988) to analyze the position of AB1 and $\mathrm{AB} 2$ in the play. AB2 has two identities, the narrator and the character. The first level is about AB2, the narrator who is outside the framing fictional world, communicates with the audience, sometimes returning to the framing fictional world to speak to AB1 and Miss Shepherd. The second level is within the framing fictional world where the character AB2 is writing about his experiences with Miss Shepherd before she dies, and we as the audience can see AB2 writing, reading to us. The third level is the most central part, belonging to the embedded fictional world, where the character AB1 communicates with Miss Shepherd, the social worker, and others. (p. 162) In analyzing the discourse structure of the play, McIntyre (2006) points out that there are four levels of communication: one-way communication between the playwright and the real-life reader or audience; one-way communication between AB2 as the narrator and the reader or viewer; one-way communication between $\mathrm{AB} 2$ as a character and $\mathrm{AB} 2$ as a character in a diary or notebook, since the play itself if a fictionalized account of Alan Bennett actually writing a play based on Miss Shepherd's life and AB2 is effectively addressing himself when he writes up his notes on Miss Shepherd in diaries and notebooks; bi-directional communication between the characters AB1 and AB2 and Miss Shepherd and the other characters. (p. 8) 
The story world in the film is discernible and closely resembles McIntyre's analysis, though it is not easy for the audience to see the various levels of communication. At the outermost level is the real world: Alan, the real author in the real world, appears on the screen. Bennett is shooting a scene about unveiling a blue plaque on the wall of the house where he lives and his introduction to Miss Mary Shepherd, none odder or more remarkable than her. The plaque reads "Miss M. T. Shepherd" and "The Lady in The Van" lived here 1974-1989. The audience then withdraw from the film and know this is a story created by a playwright named Alan Bennett. It's a one-way communication between the director and the audience.

The second level is a one-way communication between Bennett and the audience. As the narrator, Bennett tells the audience a story about his friendship with Miss Shepherd based on the process of creation of his book. At the end of the film, the audience know that the writer Bennett has published a book, entitled The Lady in the Van. This is a response to Bennett's recollection of the past as a writer at the beginning of the film.

The third level contains several levels of communication which are interwoven together: firstly, there is a two-way communication between writer-who-writes and writer-who-lives. The opening says that the story is mostly true, so what are the fictional elements? We may know this point at the end of the film, Miss Shepherd's sudden appearance at a cemetery startles Bennett who is mourning her death. Miss Shepherd asks him if she is still at the center of the story. At that moment, Bennett, the writer, appears, holding a book and wearing a slightly different coat. In the real life, it is impossible for the two Bennetts to appear in front of Miss Shepherd at the same time. However, Miss Shepherd says: "There are two of you now. Is that because you're in two minds?" She gets different answers from two Bennetts: Yes and No. As for Miss Shepherd's return from the grave, McIntyre (2006) explains that this seemingly impossible occurrence can be explained by the theories put forward in his book: the reader/audience moves not only between deictic fields but also between the alternative possible worlds of the TAW. (p. 185). We know that when the book is published, the two Bennetts exchange their views on the subject. At the end of the film, the writer-who-writes is gone, leaving the writer-who-lives alone. They become unified. Secondly, there is a bi-directional communication between Bennett, Miss Shepherd and other characters. It is also the best perspective for the audience to understand agents, circumstances, and surroundings in the story world. Bennett, the narrator or the writer-who-writes, is present throughout the film, just like AB2 moving back and forth between the fictional worlds of McIntyre's framing fictional world, and the viewer follows his point of view and gets to know the woman who lives in the van.

Miss Shepherd comes to Camden with plans of her own. She abandons her sinful name, Margaret and changes her name to Mary, but keeps it from Bennett. Bennett calls her Miss Shepherd, but the social workers call her Mary. This may imply that Miss Shepherd intentionally distances herself from Bennett and makes their friendship last for fifteen years. She is a paradox and at odds with her surroundings. She is self-employed, not a beggar. When people praise her, she is angry. She thinks she is sick and will die at any moment. She is looking for a last resting place, somewhere to lay her head. She has escaped from the Asylum which cannot imprison her soul, which is adrift, nowhere to put, and even becomes cognitively deviant. She cannot maintain a fixed abode but has a temporary habitat or the van. It is Bennett that accommodates her. Bennett is a writer who gets material from the real-life Bennett, often using his mother to tell stories in a monologue form. Bennett thinks that there is a painful symmetry between them, homeless, seemingly mad Miss Shepherd is always at ease, and Bennett's respectable mother ends up in a home in Weston-super-Mare. He thinks that putting his mother in a home is some sort of failure, giving the other a home, that is a failure, too. The two Bennetts often communicate with each other. When will they be unified? It turns out that finally Bennett's writing comes from life and touches the real humanity after he contacts with Miss Shepherd. Bennett thinks that Miss Shepherd teaches him that you don't put yourself into what you write. You find yourself there. Maybe that's the essence of the film.

The film is not about Bennett's kindness but reveals an oddity and ironically describes the British society and its people at the time: callous, selfish, contradictory and ridiculous. The gentle middle-class neighbours live in a mansion but cannot have a deep insight into life like Miss Shepherd. They have only a nodding acquaintance with Bennett, while Miss Shepherd can be his true friend and help him improve his relationship with his mother "Mam". His company soon awakens his mother who may sleep away all the time. The film is not aimed at preaching esoteric philosophy, instead presents a kind of eerie mother-child bond. The seemingly nutty Miss Shepherd is a guide in Bennett's life, teaching him how to write and how to get along with his mother.

\section{CONCLUSION}

This paper has given a detailed analysis of the film version of The Lady in the Van from three dimensions put forward by David Bordwell. As for the narration, the writer Bennett uses voice-over or as a narrator tells us his odd friendship with Miss Shepherd. The plot structure follows the traditional film structure but reveals a inextricably interwoven plot. The story world is also complex and contains many levels of communication. When the audience enter the story world, they are led by the narrator and witness the interaction between two Bennetts, Miss Shepherd and other people.

\section{ACKNOWLEDGMENTS}

I would like to thank my supervisor Weiping Du for his guidance and support when writing this thesis. I really 
appreciate his requirement of close reading of novels and theoretical research in literary stylistics. This work was supported by a grant from "Dan McIntyre's Study of Viewpoint in Plays and Other Text-Types under the Framework of Cognitive Poetics”, 2021 High-level Academic Innovation Program for Graduate Students, Capital Normal University.

\section{REFERENCES}

[1] Bordwell, David. (2008). Poetics of cinema. New York: Routledge Taylor \& Francis Group.

[2] Emmott, C. (1997). Narrative comprehension: a discourse perspective. Oxford: Oxford University Press.

[3] Fowler, R. (1977). Linguistics and the novel. London: Methuen.

[4] Harris, S. (1984). Questions as a mode of control in magistrates' courts. International Journal of the Sociology of Language, 49, 5-27.

[5] Li, Xianjie. (1999). Film narratology: theory and practice. Beijing: China Film Press.

[6] McIntyre, Dan. (2005). Logic, reality and mind style in Alan Bennett's The Lady in the Van. Journal of Literary Semantics 34.1, 21-40.

[7] McIntyre, Dan. (2006). Point of view in plays. Amsterdam/Philadelphia: John Benjamins Publishing Company.

[8] Nina Nørgaard, Rocío Montoro and Beatrix Busse. Liu Shisheng, annotation. (2017). Key terms in stylistics. Beijing: Foreign Language Teaching and Research Press.

[9] Richardson, B. (1988). Point of view in drama: diegetic monologue, unreliable narrators, and the author's voice on stage. Comparative Drama 22.3, 193-214.

[10] Ryan, M. L. (1991). Possible worlds, artificial intelligence and narrative theory. Bloomington and Indianapolis: Indiana University Press.

Xiaojuan Liu, female, is a PhD candidate of the school of Foreign Languages, Capital Normal University. She is also an associate professor of the School of Humanities, Tiangong University. Her research interest includes college English teaching and literary stylistics. 